\title{
Implementation of Integrated Marketing Communication in Image of Private Higher Education
}

\author{
Dikdik Harjadi \\ dikdik.harjadi@yahoo.com \\ Universitas Kuningan \\ Dewi Fatmasari \\ IAIN Syekh Nurjati Cirebon
}

\begin{abstract}
This study aimed to examine the implementation of integrated marketing communication conducted by private universities in Kuningan Regency and analyze the influence of integrated marketing communication performance which includes advertising, sales promotion, personal selling, public relation, and direct marketing on private university image. The method used was descriptive and verificative method conducted by collecting primary data in the field from private university students in Kuningan Regency. Based on the results of data processing and hypothesis testing, it was known that integrated marketing communication consisting of advertising, personal selling, sales promotion, public relation, and direct marketing simultaneously and partially had a positive and significant impact on private university image. The simultaneous influence is $38.7 \%$, which meant there was still much influence outside the implementation of integrated marketing communication that affected private university image. The biggest influence was sales promotion.
\end{abstract}

Keywords: advertising, sales promotion, personal selling, public relation, direct marketing, private university image

\section{INTRODUCTION}

Competition of education service sector among private universities in fighting for student "market" is quite heavy. Private universities in Indonesia now thrive like a mushroom in the rainy season. Currently, the number of private universities in Indonesia is about 3,332 institutions consisting of about 20 percent in the form of University, 50 percent in the form of Specialized College, and 30 percent in the form of Academy.

Image becomes a very important thing to be sold to prospective consumers. As Kotler \& Keller (2009) noted that image essentially involves a set of beliefs, ideas and impressions a person has for an object. The belief in an object can be owned by someone when there is a proper message transfer. In other words, how to communicate a message about an object will produce a positive effect and generate a positive image in the mind of prospective consumers if the delivery of this message is properly used in the right packaging.

Image is one of the most important assets of a university. A good image is a powerful tool not only to attract prospective students to choose majors or courses that exist in university only, but also improve student satisfaction of a university. Therefore if a positive image has been formed in the eyes of prospective students, they will be interested to go to the university and recommend it to others.

Private universities especially those in the region are still perceived to have a lower quality compared to private universities in large cities and public universities. Nevertheless, some empirical facts contribute to the condition. As stated by Ki Supriyoko in Suara Merdeka Daily (Monday Edition, March 13, 2006) which stated that in the year 2000, there is not one private university that is able to show quality on the academic stage at the regional and even international level, and the quality of the national standard is estimated to reach only $5 \%$ of the total number of private universities.

In Kuningan Regency, there are currently 5 private universities which in their development still looks like they are perceived to be not as the main choice of Private University. Most of the people still consider that the existing private universities in Kuningan Regency are second-class universities; this is certainly a negative image that affects the reduced interest of prospective students pursuing education in private universities in Kuningan Regency. 
Up until now, higher education institutions have been imaged as educational institutions that prioritize social obligation, which develops in-depth study of science because it ignores the things that come into contact with practical economic considerations. As a result, the space of movement becomes very elite and exclusive. But with the development of university autonomy applied in all public universities today, the orientation of universities began to experience a shift in orientation, which leads to the orientation of entrepreneurship.

Image becomes a very important thing to be sold to prospective consumers. As Kotler \& Keller (2009) noted that image essentially involves a set of beliefs, ideas and impressions a person has for an object. The belief in an object can be owned by someone when there is a proper message transfer. In other words, how to communicate a message about an object will produce a positive effect and generate a positive image in the mind of prospective consumers if the delivery of this message using the right packaging.

Companies in the past have often considered communication element as an activity separated from marketing, while the current marketing philosophy emphasizes the importance of integrating both to success. The underlying reason of this integrated marketing communication is that marketing communication will be the only continuing competitive advantage of a marketing organization in the 1990s into the 21 st century. According to Dissanayake (2012:27), Amaretta and Evelyn (2011), marketing communication is defined as a comprehensive plan process that adds value and strategic role of some types of communication.

Meanwhile, according to Duncan (2002:125), marketing communication is a marketing activity that seeks to disseminate information, influence or persuade and remind the target market of companies and products to be willing to accept and buy on products offered. Integrated marketing communication according to Mubushar et.al (2013) include advertising, personal selling, sales promotions, public relation, and direct marketing. Advertising is a marketing communication medium that has become an integral part of society and human economic system. Advertising needs the most accurate promotional methods possible because the impact is so great to the audience, both in terms of message content and submission.

Direct promotion through individuals is called personal selling. Personal selling has a direct effect on sales process based on sales forces. The most important reliability of personal selling is indeed able to bring customers closer with sales through the use of channels of distribution of goods and products available. Through this personal selling, customers will not be hesitating to ask and find out the ability of these products freely. They, the companies, will also be able to get accurate information, the good and bad side of the product directly from consumers.

Sales Promotion is a form of direct persuasion through the use of variety of intensive that can be set to stimulate the purchase of products immediately and/or increase the amount of goods purchased by customers. Through sales promotion, the company can attract new customers, influence its customers to try new products, encourage customers to buy more, attack competitors' promotional activities, improve impulse buying, or seek closer cooperation with retailers.

Public Relation, this marketing communication, it can be said to be constant. This tool will build a very slow marketing effect as a supporter of other communication functions to the customer as a reinforce of product credibility. For example, companies provide assistance to communities around the corporate environment by contributing to their welfare with humanitarian activities and others. Fostering good relationships with creating community development is a strategy that is very telling and good because it is sustainable for the company.

The development of transportation and communication technology has provided many opportunities for direct marketing optimization. Communication technology allows marketers to use a variety of channels to reach target buyers or customers broadly and easily. Thanks to technology, the following are direct marketing forms that can be done by marketers through various possible channels: Face-to-face Sales, By Email, Telemarketing, and Online Marketing

Mahadzirah \& Awang (2009), Helgesesn \& Nesset (2007), Alves \& Raposo (2007) concluded that the image is an award obtained by the company because of the advantages that exist in the company, such as the ability owned by the company, so the company will continue to develop itself to continue to create new things again for the fulfillment of consumer needs. Consumers in buying and consuming goods or services not just expect merely goods or services, but there is something else, something else that fit with the image that formed in them. This image is formed based on the impression or experience experienced by someone on something, so that in the end, it builds a mental attitude. This mental attitude will be used as a consideration to make decisions because the image is considered to represent the totality of one's knowledge of something. Every institution including private university should always try to improve its image. Polat and Hezer (2011) mentioned some elements of the image of the institution/ private university: Personality, Reputation, Value/Ethics and Corporate identity.

Based on the above description, the problem in this research can be formulated as followed: how the influence simultaneously and partially of each elements of integrated marketing communication on Private University image is. Proposed hypotheses are advertising, personal selling, sales promotions, public 
relation, and direct marketing as integrated elements of marketing communication simultaneously and partially have positive effect on private university image.

\section{METHODS}

The method used was descriptive method which was a research that aimed to obtain a description of the perception of integrated marketing communication and private university image. This research also used verificative method that aimed to test the hypothesis that had been determined. The data collection used two survey methods, namely descriptive survey and explanatory survey conducted by collecting primary data from university students.

The population is university students in Kuningan Regency as many as 8,063 people who then using Slovin formula calculated sample size obtained as many as 381 people, shown in Table 1.

Table 1. Population and Sample

\begin{tabular}{rlrr}
\hline No. & \multicolumn{1}{c}{ Higher Education } & $\begin{array}{c}\text { Total } \\
\text { Population }\end{array}$ & $\begin{array}{c}\text { Total } \\
\text { Sample }\end{array}$ \\
\hline 1 & Universitas Kuningan & 4.427 & 209 \\
2 & Universitas Islam Al-Ihya & 548 & 26 \\
3 & STKIP Muhammadiyah & 2.349 & 111 \\
4 & STIKes Kuningan & 663 & 31 \\
5 & AKFAR Muhammadiyah & 76 & 4 \\
\hline & Total & 8.063 & 381 \\
\hline
\end{tabular}

The number of respondents was 381 people with proportional random sampling, that was sampling based on the proportion of the number of students of each private university in Kuningan Regency. The integrated marketing communication variables consist of several dimensions: advertising, personal selling, sales promotion, public relation, direct marketing. Each dimension could be measured with the following indicators: advertising (ad reach, ad media selection, advertising frequency), personal selling (promotional officer appearance, marketer ability, marketer responsiveness), sales promotion (fee deductions, rewards, bonuses, scholarships), public relation (publication information, public service announcements, special events, sponsorship), direct marketing (website, telephone, marketer) and institutional image (personality, reputation, values, institutional identity).

Each indicator was measured by ordinal scale in which each indicator was inserted into the items of the statement contained in the questionnaire. Data were collected by questionnaire where each component of integrated marketing communication was measured with 10 items of statement, and private university image was measured with 14 items of statement. After going through the test of each instrument statement items, it was then declared valid and reliable. Based on the normality test data obtained, the data researched was in the normal category. The influence of integrated marketing communication on private university image used multiple linear regression analysis technique.

\section{RESULTS}

The regression equation resulting from advertising, personal selling, sales promotion, public relation, direct marketing and institutional variables can be seen in Table 2.

Table 2. Multiple Linier Regression Equation Coefficients $^{\mathrm{a}}$

\begin{tabular}{cccccc}
\hline & \multicolumn{2}{c}{$\begin{array}{c}\text { Unstandardized } \\
\text { Coefficients }\end{array}$} & $\begin{array}{c}\text { Standardized } \\
\text { Coefficients }\end{array}$ & & \\
\cline { 2 - 5 } Model & $\mathrm{B}$ & Etd. & & \\
\cline { 2 - 5 } $1 \quad$ (Constant) & 36.551 & 2.802 & & 13.043 & .000 \\
$\mathrm{X}_{1}$ & .038 & .064 & .038 & 2.595 & .012 \\
$\mathrm{X}_{2}$ & .072 & .078 & .066 & 2.925 & .005 \\
$\mathrm{X}_{3}$ & .349 & .059 & .317 & 5.903 & .000 \\
$\mathrm{X}_{4}$ & .037 & .066 & .038 & 2.564 & .013 \\
$\mathrm{X}_{5}$ & .207 & .069 & .195 & 2.997 & .003 \\
\hline a. Dependent Variable: $\mathrm{Y}$ & & & &
\end{tabular}

Based on Table 2, multiple linear regression equations for advertising, personal selling, sales promotion, public relation, direct marketing, and institutional image represented by column B lay in unstandardized coefficients, and multiple linear regression equation of the three variables is:

$$
\begin{aligned}
\hat{\mathrm{Y}}= & 36.551+0.038 \mathrm{X}_{1}+0.072 \mathrm{X}_{2}+0.349 \mathrm{X}_{3}+0.037 \mathrm{X}_{4} \\
& +0.207 \mathrm{X}_{5}
\end{aligned}
$$

Coefficient of determination analysis is used to know the contribution of influence of independent variable on dependent variable is. The results of the simultaneous coefficient of determination can be seen in Table 3.

Tabel 3. Coefficient of Determination Analysis Result Model Summary

\begin{tabular}{ccccc}
\hline Model & $\mathrm{R}$ & $\mathrm{R}$ Square & $\begin{array}{c}\text { Adjusted } \mathrm{R} \\
\text { Square }\end{array}$ & $\begin{array}{c}\text { Std. Error of } \\
\text { the Estimate }\end{array}$ \\
\hline 1 & $.622^{\mathrm{a}}$ & .387 & .131 & 1.913 \\
\hline a. Predictors: (Constant), $\mathrm{X}_{5}, \mathrm{X}_{4}, \mathrm{X}_{3}, \mathrm{X}_{2}, \mathrm{X}_{1}$ &
\end{tabular}

Based on the results of the data using SPSS model summary in Table 3, it is shown that R value is 0.622 . It also shows the relationship between all independent variables to private university to image is 0.622 . Further 
obtained R Square equal to 0.387 which means that $38.7 \%$ is the influence of advertising, personnal selling, sales promotion, public relation and direct marketing on private university image, and the rest $(61.3 \%)$ are explained by other causes outside the research.

\section{DISCUSSION}

Partial hypothesis test result can be explained that advertising variable has a positive and significant effect on private university image. This shows that if the advertising activity is done effectively, it will be able to improve the image of private university. This is in line with the results of Chih Huang.et.al (2010) and Al-Khattab, et.al, (2015). Advertising as a one-way communication conducted by the private university to the public will provide a variety of information visually which then the information will affect the public perception about the private university. Therefore every private university should plan and manage its advertising by paying attention to the content of information to be conveyed as well as advertising media used so that the message or information conveyed is able to give positive perceptions to the community.

Personal selling shows a significant positive effect on private university image. This indicates that the more interesting the personal selling program is done will improve the private university image. Personal selling activities where the marketers directly convey information to prospective students and the wider community should be able to give a positive impression because it will then determine the perception of prospective students and the public about the image of the private university. The results of this study are in line with Messah \& Immaculate (2016) and Bylon \& Atara (2013).

Sales promotion shows a significant positive effect on private university image. This indicates that the more interesting sales promotion activities will improve the image of private university. The results of this study are in line with the results of study by Allaham (2015) and Bylon \& Atara (2013). The activity of sales promotion through the giving of tuition fee, scholarship and other incentive to prospective students will perceive good image from prospective students on private university. Private university can explore new ideas in providing attractive incentives for prospective students.

Public relation shows a significant positive effect on private university image. The more effective public relation is done, it will further enhance private university image. This is in line with research results from Alhadid \& Qaddomi (2016) and Singh \& Pandey (2017). Public relation activities as a private communication activity undertaken to influence public opinion that can change the behavior of prospective students can play an optimal role when the information conveyed through various media can be effectively accepted by prospective students.
Based on the data analysis, it can be known that direct marketing variable shows a positive and significant impact on private university image. This is in line with the results of research by Fatos Ukaj (2016). The use of information technology in delivering messages to the public through web-sites, social media and other media can form a positive opinion if it is managed effectively.

Based on the results of data analysis and hypothesis testing, it can be seen that the overall component of integrated marketing communication will determine the image of private university. This result is in line with Estaswara (2011) research; Fard and Faharani (2015); Hamidreja and Morteza (2017); Pino \& Lynagh (2006) that in order to improve the image, it is appropriate to continuously improve the quality of marketing communication activities appropriately. The results of data analysis also shows that among the five components of integrated marketing communication, sales promotion gives the largest contribution to the image of the institution compared to other components. It is realized that through scholarship activities or tuition waivers, student acceptance through academic achievement as well as economically disadvantaged students will provide a positive image of private university in the community. This is based on the idea that these programs are perceived as a form of awareness of private universities towards community.

\section{CONCLUSION}

Based on the results of research and data analysis, it can be concluded that the elements of integrated marketing communication which includes advertising, personal selling, sales promotion, public relation and direct marketing simultaneously had influence positive and significant effect on private university image. This means that the more effective the activities of each element of integrated marketing communication is, it will also improve private university image.

The magnitude of influence of integrated marketing communication, which include advertising, personal selling, sales promotion, public relation and direct marketing on private university image is $38,7 \%$ and the rest influenced by other variable outside the research. The influence of the largest variable is sales promotion, as a form of awareness of private universities towards community.

\section{REFERENCES}

Allaham, 2015, The effect of sales promotion tools on brand image, International journal of Business and Management invention, Vol.4. Issue 2.

Alhadid \& Qoddomi, 2016, The role of public relation on company image: social media as a moderating variable: a case study at the applied science private 
university at Jordan, International journal of academic research in business and social science, Vol.6 No,4.

Al-Khattab, et.al, 2015, E-Integrated Marketing Communication and Its Impact on Customer Attitudes, American Journal of Industrial And Business Management, 2015.

Alves and Raposo, 2007 "The influence of university image in Student's Expectation, Satisfaction and Loyalty", The European Education Society, Universitat Innsbruck, Austria.

Ammaretta \& Evelyn, 2011, The Effect of Marketing Communication and Price Promotion to Brand Equity, The 2 nd International Research Symposium In Service Management, Yogyakarta.

Bylon \& Atara. 2013. The role of marketing communication in student enrolment in private universities in Ghana, Global advanced research journal of management and business studies, Vol.2 (5).

Chih, Huang, et.al, 2010, The Study of Integrated Marketing Communication for Non-Profit Organization: An Empirical Study of Corporate Foundation In Taiwan, National Dong Hwa University, Taiwan

Dissanayake, 2012, Integrated Marketing Communication and Corporate Reputation: Evidance From Dell Computer Corporation, International Refereed Research Journal, Vol.III Issue-3(1) July 2012.

Duncan, T., 2002. IMC: Using Advertising \& Promotion to Build Brands. McGraw Hill, New York.

Estaswara, 2011, The Implementation Process of Integrated Marketing Communication And Its Prospect In Business Practice In Indonesia: An Explanatory Comparative Study Toward Four Proffesion Group, The Indonesian Journal Communication Study.

Fard \& Farahani, 2015, Integrated Marketing Communication and its impact on the development of customer-based brand equity in the insurance industry (case study: pasargad insurance), Indian Journal of Fundamental and Applied Life Science: Vol 5, 2015.
Hamidreja \& Morteza. 2017. The impact of advertising and sales promotion on brand loyalty through brand equity, International journal of basic science \& applied research, Vo. 6 (1)

Helgesen and Nesset. 2007. "Image, Satisfaction, and Antecedent: Drivers of Student Loyalty? A Case Study of A Norwegian University College, Corporate Reputation Review, Vol 10 No.1, Palgrave Macmillan,Ltd.

Kotler and Keller. 2009. "Manajemen Pemasaran", Jilid 1 dan 2. Edisi 13, Penerbit Erlangga, Jakarta, 2009.

Mahadzirah and Awang. 2009. "Building corporate image and securing Student Loyalty in The Malaysian Higher Learning Industri" mengkaji empat variabel yaitu: Service quality, Corporate Image, Student Satisfaction dan Student Loyalty", The Journal of International Management Studies, Vo. 4 No.1 February, 2009

Messah \& Immaculate. 2016. "Effect of selected marketing communication tools on student enrolment in private universities in Kenya" European Journal of Business and Management, Vol.3.No.3

Mubushar, et.al. 2013. The Effect of Integrated Marketing Communication on Customer Based Brand Equity With Mediating Role of Corporate Reputation in Cellular Industry of Pakistan, Global Journal of Management \& Business Research Marketing: Volume 13 Issue 6, 2013.

Polat and Hezer. 2011. "Relation Between Organizational Image and Organizational Trust In Education Organizations", International Journal of Education Administration and Policy Studies, Vol.3 (9) September 2011

Pino \& Lynagh. 2006. Integrating Exibit Marketing Into Integrated Marketing Communication, Journal Of Consumer Marketin

Singh \& Pandey. 2017. Role of public relation in image management of an organization, International journal of advance research, idea and innovation in technology, Vo.3.Issue 4.

Ukaj. 2016. "Direct marketing: an imperative in building effective communication in hospitality enterprise", European scientific journal, vol.12 no. 10 . 